\title{
Influence of communication tools on customer behaviour within a food product after declared consumption date in global retail
}

\author{
Pavel Mráček ${ }^{1}$, and František Milichovský1,** \\ ${ }^{1}$ Brno University of Technology, Faculty of Business and Management, Department of Management, \\ Kolejní 2906/4, 61200 Brno, Czech Republic
}

\begin{abstract}
.
Research background: Marketing communication should catch the attention of target customers, who pay attention to advertisements to make an interest in product, service, brand, or company. Marketing communication can impact customers behaviour in food choice due to association with personal identity, which is important interpersonal communication to others.

Purpose of the article: Customers purchase a lot of food with no matter the possibility of consumption. Therefore, a lot of foods are wasted or degraded for consumption, because of health risks. It is necessary to influence target customers and change their mind setup and their purchasing behaviour in global retail chains.

Methods: As primary research, a questionnaire survey was used. For the survey was asked 1042 persons to participate. From asked persons, we receive 451 questionnaires, which mean $43,28 \%$. In the amount of returned questionnaires, we had to remove 23 lists as incomplete. The total complete forms were 428 ( $41,08 \%$ of asked). For the evaluation of gained data, there was applied Pearson's chi-square test for independence of variables.

Findings \& Value added: Customers behave according to the presented message in communication tools, which they believe. Therefore, it is possible to use communication tools on the way of recipient behaviour cultivation. The main objective of the paper is to find a connection between marketing communication tools and customer behaviour within food products after the declared consumption date. For evaluation, there were used five variables of customer behaviour with food, and seven chosen marketing communication tools. From 35 possible connections, we found out dependencies for ten relations.
\end{abstract}

Keywords: marketing communication tools; food product; date of consumption; global retail; customer behavior

JEL Classification: L81; M31; Q53

\footnotetext{
*Corresponding author: milichovsky@ffbm.vutbr.cz
} 


\section{Introduction}

Customers' behaviour is a key factor in care within a food product, especially after date expiration. The kind of care should be different according to the kind of food. At present time, a lot of people begin with care about products after usage purposes. All potential problems are included in reverse logistics. The specific area of care after usage purpose is with food. There is usual behaviour when consumers buy a bigger amount of food products and do not consume them and therefore they waste food. Ways of re-usage food products before expiration date have become a close part of day-to-day life. It is necessary to motivate customers to better food care and change their mind-set. It is possible to find the most suitable way how to use foods before expiration, such as delivering to food banks or providing necessary [1].

The starting motivator of relevant behaviour with food care could be started by correct marketing communication, especially by non-traditional communication tools. By adequate marketing campaigns, customers reach desire with food care and stabilize it. Food care is connected with sharing food before expiration with necessary or putting food after expiration to the right food waste of compost [2].

\subsection{Non-traditional marketing communication tools affecting customer behaviour}

Awareness of potential target customers is usually influenced by relevant marketing communication tools. Within the application of all marketing communication tools, it could be crucial to catch the customer's interest and pull him to purchase [3]. Customer's interest and awareness need to have adequate information in communication messages that can help to reach a final decision about a final purchase. Customers get enough adequate information about a product, brand, and other conditions, influencing their purchase.

From point of marketing communication view, communication tools should be everything (both known and unknown ways), by which the company could share a suitable message (does not matter about the content) with the target market or audience. As basic communication tools are stated public relations, direct marketing, advertising, sales promotion. If companies use the online environment, then it's possible to renew other tools such as viral and guerrilla marketing, word of mouth, or online media [4-5].

As fundamental of the marketing communication process is the application of the interpersonal communication model in an adaptation by the AIDA approach. AIDA is regarded as a traditional tool, which is used as a base for various development, e.g. CAB approach with only three steps process instead of four in AIDA. These three steps include (1) cognition, by which is gained awareness of the target subject help to provide relevant information, (2) effect is focused on customer's feelings, interests, and desires in linking of communicated product, and finally, (3) behaviour of customer pointed to purchase or eventually borrow. As the whole model, $\mathrm{CAB}$ presents a more flexible tool to bias target customers in the purchasing process [6].

From a general point of view, marketing communication target on position and behaviour of customers, that receive the marketing message. Important is to target customers not only during mass media but especially in the purchasing decision-making process, where are much sensitive to be affected. Thanks to globalization and making narrow supply chains there are a lot of connections between producer, seller, or distributor when all of them can influence customers worldwide, increase the relevance of the product and offer suitable information packet to the customer as a map at the market [7-8]. The specific situation is in marketing communication at the food market, where customers are more impressible for any changes in a production line, country of origin, or price policy [2]. 
In the present, marketers usually use communication tools with high control level of the flow due to traditional media. In the context of the new technologies, there is an expected model with high interactivity in whole communication.

Traditional communication tools offer the possibility to impact a large audience by mass media (e.g. TV, newspapers and magazines, outdoor tools, or radios). By digitalization of media by using the internet marketers get more interactivity, which sustainable their activities and generate customer's feedback [9]. A set of non-traditional communication tools offers the possibility to impact target customers directly with a lower budget and other sources, which helps to reach high marketing effectiveness. As key steps, Tomek and Vávrová [10] mentioned five steps customers have to get in contact, awareness, attitude, intention, and purchase. Usage of these phases is depended on the way, how customers make a purchase decision; are they impulsive or they are reasonable during purchase. Therefore, there are three possible situations how marketers can change potential customer into a real one (see Figure 1).

\begin{tabular}{|c|c|c|c|c|c|}
\hline Impulsive decision & contact & awareness & purchase & & \\
\hline Arise interest & contact & awareness & intention & purchase & \\
\hline Extension decision & contact & awareness & attitude & intention & purchase \\
\hline
\end{tabular}

Fig. 1. Approaches to change potential customers into a real customers.

If the marketing message should impact the target customer, it is important to know specific characteristics according to defined corporate strategy in connection to product and marketing communication strategy. Then, adequate planning of marketing communication is possible to fulfill customer's needs and reach business success. The creation of a marketing communication strategy has to be based on knowledge of the defined marketing objectives, target groups, and actual market analysis.

\subsection{Food waste and customer behaviour}

The food industry could be considered as a crucial field for every national economy. According to Visschers et al [1], the typical consumer in Europe throws out almost $115 \mathrm{~kg}$ per year, especially in western countries. Households produce more food waste in comparison to restaurants [11]. In the case of large families is food-waste production in more amount against small families. This situation was proved by many researchers, which focused on food waste such Withanage et al. [12], Thyberg, and Tonjes [13], Astill et al. [14], or Secondi et al. [15]. These researchers defined the potential connection of customer food behaviour with the age of preparing a person. The older preparing person generates less waste; on the contrary, older person, which purchase food, usually buy large-size packages that lead to making wastage.

As a kind of prevention of food waste, it is important to arrange the food supply chain in the correct way as prevention early purchased food. At the same time, there could be a key impact of marketing communication tools employed by sellers [2], which affects the thinking of households $[16,17]$.

As the optimization process of waste generation, there is possible to apply the concept of reverse logistics in the specification of the food industry. The base for the optimization is the phase specification of consumption. Moraes et al [18] defined two phases of consumption. First is put to after-sale as a close connection to planning, control, and disposition of purchased products without their usage and sending back do the supply 
chain. Usually, a customer wants to put the product back - usually due guarantee problem. The second phase is called as after-consuming when the product is almost at the expiration date and is suitable and ethical to find new alternative disposition or recycling instead of burning or landfilling.

\section{METHODOLOGY}

The main objective of the paper is to find a connection between marketing communication tools and customer behaviour within food products after the declared consumption date. The main hypothesis is, that non-traditional marketing communication tools do not affect ways of food usage after food shelf time. This hypothesis was transformed into a statistical version:

- $\mathrm{H}_{0}$ : There is no relationship between non-traditional marketing communication tools and ways of food usage after food shelf time

- $\mathrm{H}_{1}$ : There is a relationship between non-traditional marketing communication tools and ways of food usage after food shelf time

As primary research, the questionnaire survey was used. For the survey, 1042 persons were asked to participate. The questionnaire survey was realized during January 2020 in the market of the Czech Republic. From asked persons, we receive 451 questionnaires, which mean $43,28 \%$. In the amount of returned questionnaires, we had to remove 23 lists as incomplete. The total complete forms were 428 (41,08\% of asked persons). For the evaluation of gained data, there was applied Pearson's chi-square test for the independence of variables with valuation by the contingency coefficient.

\section{RESULTS}

There was employed Pearson's chi-square test of independence to evaluate the stated hypothesis, that "non-traditional marketing communication tools do not affect ways of food usage after food shelf time". Because of a lot of potential combinations of chosen variables (35 combinations), the stated hypothesis is divided into individual parts according to variables. As non-traditional communication tools are usually considered

- Guerrilla marketing;

- Engagement marketing;

- Gamification;

- Viral marketing;

- Astroturfing;

- Ambient media;

- Influencers.

As potential usage of food expiration, which is close to and after the date, there is possible to find:

- Displace to municipal waste;

- Displace to biowaste;

- Put to composting;

- Hand over to food bank;

- Hand over to local people in need.

For evaluation was used an applied test of dependency with the paucity of external influence. According to the described theory, there is an assigned hypothesis, which had to be transformed into a statistical hypothesis. This statistical hypothesis is suggested in the null form. If the significance of the dependence is found out, then the alternative hypothesis 
is accepted, and the final expression is a change from "there is no dependence" to "there exists dependence".

From the realized test of independence, there was employed Pearson's chi-square test for independence. Due to the processing of the data, there was important to reach the significance level of $95 \%$. This level could be described as the situation when is possible to identify $5 \%$ fault in case of choosing an alternative hypothesis. The error value is recall as significance, regarded as a level of reliability. If the significance value is under 0,05 than is necessary to choose the alternate hypothesis and make a conclusion about the existence of dependence between chosen variables.

In Table 1 there are shown results of the Pearson chi-square test of independence, which are connected to defined hypothesis H1. From these results, there is found ten dependencies on the $95 \%$ significance level, which reached a significance value of under 0.05 . According to a previous note there, only one dependence was found:

- Guerilla marketing and local people in need ( $\operatorname{lign} .=0,041$, cont. coef. $=0,201$ );

- Engagement marketing and municipal waste ( $\operatorname{sign} .=0,004$, cont. coef. $=0,233$ );

- Engagement marketing and bio waste ( $\operatorname{lign} .=0,014$, cont. coef. $=0,217$ );

- Engagement marketing and composting (sign. $=0,027$, cont. coef. $=0,208$ );

- Gamification and municipal waste ( $\operatorname{sign} .=0,048$, cont. coef. $=0,198$ );

- Gamification and bio waste ( sign. $=0,003$, cont. coef. $=0,238$ );

- Astroturfing and bio waste ( sign. $=0,035$, cont. coef. $=0,203$ );

- Astroturfing and composting ( sign. $=0,003$, cont. coef. $=0,2038$ );

- Ambient media and bio waste (sign. $=0,038$, cont. coef. $=0,202$ );

- Influencers and bio waste (sign. $=0,003$, cont. coef. $=0,238$ ).

For the rest of the potential combination, there is important to choose a null hypothesis, which declares no statistical dependence between two variables.

Table 1. Observed dependencies between non-traditional communication tools and usage after food shelf time

\begin{tabular}{|c|c|c|c|c|c|c|c|c|c|c|}
\hline & \multicolumn{2}{|c|}{$\begin{array}{c}\text { Municipal } \\
\text { waste }\end{array}$} & \multicolumn{2}{c|}{ Biowaste } & \multicolumn{2}{c|}{ Composting } & \multicolumn{2}{c|}{ Foodbank } & \multicolumn{2}{c|}{$\begin{array}{c}\text { Local people } \\
\text { in need }\end{array}$} \\
\cline { 2 - 11 } & $\chi^{2}$ & Cont. & $\chi^{2}$ & Cont. & $\chi^{2}$ & Cont. & $\chi^{2}$ & Cont. & $\chi^{2}$ & Cont. \\
\hline $\begin{array}{c}\text { Guerilla } \\
\text { marketing }\end{array}$ & 0,414 & 0,147 & 0,988 & 0,072 & 0,180 & 0,172 & 0,525 & 0,138 & 0,041 & 0,201 \\
\hline $\begin{array}{c}\text { Engagement } \\
\text { marketing }\end{array}$ & 0,004 & 0,233 & 0,014 & 0,217 & 0,027 & 0,208 & 0,450 & 0,144 & 0,216 & 0,167 \\
\hline Gamification & 0,048 & 0,198 & 0,003 & 0,238 & 0,264 & 0,162 & 0,588 & 0,133 & 0,844 & 0,108 \\
\hline $\begin{array}{c}\text { Viral } \\
\text { marketing }\end{array}$ & 0,270 & 0,160 & 0,085 & 0,187 & 0,051 & 0,197 & 0,354 & 0,152 & 0,271 & 0,161 \\
\hline $\begin{array}{c}\text { Astroturfing } \\
\text { Ambient } \\
\text { media }\end{array}$ & 0,310 & 0,157 & 0,035 & 0,203 & 0,003 & 0,238 & 0,242 & 0,164 & 0,056 & 0,195 \\
\hline Influencers & 0,618 & 0,130 & 0,003 & 0,238 & 0,463 & 0,143 & 0,217 & 0,167 & 0,578 & 0,134 \\
\hline
\end{tabular}

\section{CONCLUSIONS}

Influencing of customers by relevant marketing communication in right way should have positive effect on their thinking and purchasing habits, which lead to responsible behaviour. If the marketing communication is set up correctly, then there exist closed relationship within consumer behaviour. To prevent food wasting and nature environment with minimal 
potential negative impact, it is crucial to focus on households and change their mind as solution for making prediction of their total consumption, supported by motivation from ethical, moral and social areas. The achievement of the reduction food waste is totally based on psychology influence [19].

There was the defined hypothesis that "exists a relationship between non-traditional marketing communication tools and ways of food usage after food shelf time". To evaluate the hypothesis, there was applied statistical Pearson's chi-square test for independence for five variables at a solution of food waste and seven variables of non-traditional marketing communication. There were tested 35 connections. From that count, there were proved dependencies ten connections (see Table 1). All significant relationships reach value in interval from 0 to 0,048 (the highest value for acceptance is 0,05 ). The power of the relationships is given by the contingency coefficient and all values could be considered as rather medium. The rest of the twenty-five connections do not have statistical significance to accept the dependence for them.

The results of the survey are supported by mentions of researchers (such $[2,8,14,16$, 19]) who put personal food waste prevention as an important decision in connection to consumer behaviour in a global worldwide context.

\section{References}

1. Visschers, V. H. M., Wickli, N., Siegrist, M. (2016). Sorting out food waste behaviour: A survey on the motivators and barriers of self-reported amounts of food waste in households. Journal of Environmental Psychology, 45, 66-78.

2. Kasza, G., Szabó-Bódi, B., Lakner, Z., Izsó, T. (2019). Balancing the desire to decrease food waste with requirements of food safety. Trends in Food Science \& Technology, 84, 74-76.

3. Koudelková, P. (2017). Marketing communication of SMEs acting in creative tourism. In A. Királ'ová (Eds.) Driving tourism through creative destinations and activities. Hershey: IGI Global, 375.

4. Vysekalová, J., Mikeš, J. (2007). Reklama: Jak udělat reklamu. 2. akt. a roz. vyd. Praha: Grada Publishing.

5. Kollárová, D. (2020). Globalisation and its impact on the creation of sustainable points of purchase. SHS Web of Conferences, 74, 04011.

6. Kollárová, D. (2014). Podpora predaja pri komunikácií s vybranými cielovými skupinami. Trnava: Fakulta Masmediálnej Komunikácie, Universita Sv. Cyrila a Metoda v Trnave.

7. Bearden, W.O., Ingram, T.N., Laforge, R.W. (2001). Marketing, Principles and perspectives. 3rd ed. Boston: McGraw-Hill.

8. Kumar, N., Kapoor, S. (2015). Does the consumers' buying behavior differ for vegetarian and non-vegetarian food products? Evidences from an emerging market. British Food Journal, 117(8), 1998-2016.

9. Winer, R.S. (2009). New communications approaches in marketing: Issues and research directions. Journal of Interactive Marketing, 23(2), 108-117.

10. Tomek, G., Vávrová, V. (2011). Marketing: Od myšlenky k realizaci, 3.vyd. Praha: Professional Publishing.

11. Kummu, M., de Moel, H., Porkka, M., Siebert, S., Varis, O., Ward, P.J. (2012). Lost food, wasted resources: Global food supply chain losses and their impacts on 
freshwater, cropland, and fertiliser use. Science of the Total Environment, 438, 477489.

12. Withanage, S.V., Dias, G.M., Habib, K. (2021). Review of household food waste quantification methods: Focus on composition analysis. Journal of Cleaner Production, 279, 1-15.

13. Thyberg, K.L., Tonjes, D.J. (2016). Drivers of food waste and their implications for sustainable policy development. Resources, Conservation and Recycling, 106, 110123.

14. Astill, J., Dara R.A., Campbell, M., Farber, J.M., Fraser, E.D.G., Sharif, S., Yada, R. Y. (2019). Transparency in food supply chains: A review of enabling technology solutions. Trends in Food Science \& Technology, 91, 240-247.

15. Secondi, L., Principato, L., Laureti, T. (2015). Household food waste behaviour in EU27 countries: A multilevel analysis. Food Policy, 56, 25-40.

16. Hebrok, M., Boks, C. (2017). Household food waste: Drivers and potential intervention points for design - An extensive review. Journal of Cleaner Production, 151, 380-392.

17. Mondéjar-Jimenéz, J.-A., Ferrari, G., Secondi, L. (2016). From the table to waste: An exploratory study on behaviour towards food waste of Spanish and Italian youths. Journal of Cleaner Production, 138, 8-18.

18. Moraes, D.G.S.V.M., Rocha, T.B., Ewald, M.R. (2014). Life cycle assessment of cell phones in Brazil based on two reverse logistics scenario. Production, 24(4), 735-741.

19. Graham-Rowe, E., Jessop, D.C., Sparks, P. (2015). Predicting household food waste reduction using an extended theory of planned behaviour. Resources, Conservation and Recycling, 101, 194-202. 